\title{
REFRIGERATED POULTRY BREAST FILLETS PACKED IN MODIFIED ATMOSPHERE AND IRRADIATED: BACTERIOLOGICAL EVALUATION, SHELF LIFE AND SENSORY ACCEPTANCE
}

\author{
Samira Pirola Santos Mantilla1*, Érica Barbosa Santos ${ }^{1}$, Mônica Queiroz de Freitas ${ }^{1}$, Helio de Carvalho Vital², Sérgio \\ Borges Mano ${ }^{1}$, Robson Maia Franco ${ }^{1}$
}

${ }^{1}$ Universidade Federal Fluminense, Departamento de Tecnologia de Alimentos, Niterói, RJ, Brasil; ${ }^{2}$ Centro Tecnológico do Exército, Rio de Janeiro, RJ, Brasil.

Submitted: February 24, 2010; Approved: June 07, 2012.

\begin{abstract}
In the present study the effects on shelf life and sensory acceptance of gamma-irradiated refrigerated poultry breast fillets subjected to modified atmosphere packaging $\left(80 \% \mathrm{CO}_{2} / 20 \% \mathrm{~N}_{2}\right.$ or vacuum) were investigated. After irradiation with $2 \mathrm{kGy}$, sensory acceptance tests and monitoring of bacterial growth were performed in order to determine the sanitary quality of the samples. It has been found that irradiation, used in combination with modified atmosphere packaging, can double the shelf life of refrigerated poultry breast fillets by reducing the populations of aerobic mesophilic and psychrotrophic bacteria, enterobacteria, coliforms, Listeria spp. and Aeromonas spp., without significantly modifying its color or its overall appearance, the lactic acid bacteria being the most resistant to exposure to radiation and carbon dioxide.
\end{abstract}

Key words: Irradiation, poultry breast, modified atmosphere, sensory acceptance.

\section{INTRODUCTION}

As an important source of proteins, poultry meat has a high biological value and it has been frequently recommended for its nutritious low fat content. However, it is also a highly perishable product that has a relatively short shelf life even when it is kept in refrigeration. Thus, developing more appropriate technologies for conservation of poultry meat still remains a goal that the scientific community has been eagerly pursuing.

Modified atmosphere packaging (MAP) is a method that consists of the removal of air followed by its replacement with a gas or gas mixture, depending on the type of product (23).
Three gases are commonly used in food packaging: $\mathrm{O}_{2}, \mathrm{~N}_{2}$ and $\mathrm{CO}_{2}$. Each has an specific function: $\mathrm{O}_{2}$ generally stimulates the growth of aerobic bacteria while inhibiting the growth of anaerobic ones; $\mathrm{CO}_{2}$ is an inhibitor of bacterial growth and fungus; whereas $\mathrm{N}_{2}$ is used as a filling gas, replacing $\mathrm{O}_{2}$ as an alternative to vacuum packaging when the product is fragile or when there is a need to prevent the collapse of the package due to the absorption of $\mathrm{CO}_{2}$ by the product $(6,7)$.

Researchers in food microbiology have demonstrated that MAP is able to increase the shelf life of various foods although usually not sufficing to effectively eliminate spoilage microorganisms, including the pathogenic species when not used in combination with other processes. On the other hand,

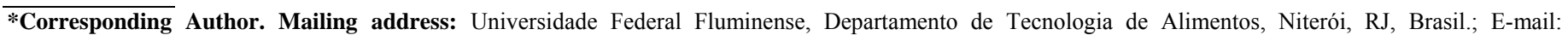
samiramantilla@yahoo.com.br 
according to the scientific literature $(5,17)$, gamma irradiation used in combination with MAP has been efficiently used in the production of safe food.

Irradiation can reduce the populations of spoilage pathogenic microorganisms and sterilize survivors, while MAP suppresses the growth of survivors during storage. Irradiation together with MAP could also act synergistically to eliminate bacteria. In addition, since many lactic acid bacteria are known to produce antimicrobicrobial compounds that have inhibitory effect on the pathogenic microorganisms, their growth in irradiated MAP and vacuum packs during storage could render an additional protection to such products $(18,28)$.

Gamma radiation is a type of ionizing electromagnetic radiation emitted from radionuclides such as ${ }^{60} \mathrm{Co}$ and ${ }^{137} \mathrm{Cs}$ and exposure to it is one of the cheapest ways food preserve foods (9). The intensity of the effects of ionizing radiation become larger proportionally to the radiation dose, also depending on the radioresistance of the microorganisms (10, 31). Its combination with other processes can turn smaller doses effective to ensure the microbiological stability of the product during distribution, marketing and consumption with lower chances of changes in nutritional and/or sensory characteristics (27).

The aim of this work was to evaluate the combined effect of MAP and low dose gamma radiation on the quality of fresh poultry breast fillet using bacteriological and sensory analyses.

\section{MATERIALS AND METHODS}

\section{Packing and irradiation treatments}

The experiments were performed in two phases. On the first day (day zero) of the first phase, $5 \mathrm{~kg}$ of refrigerated poultry breast fillets were purchased in a market in Niterói, RJ and transported in insulated polystyrene boxes with ice to the Laboratory of Microbiological Control of Animal Products of the Fluminense Federal University.

Poultry samples were aseptically divided in 40 pieces of $18 \mathrm{~g}$ each and were individually packed in nylon multilayered pouches having a low permeability to oxygen $\left(60 \mathrm{~cm}^{3} / \mathrm{m}^{2}\right.$.day). Four groups of samples were tested: 1) control (Air/0kGy), 2) vacuum-packed (Vacuum/0kGy), 3) air-packed and irradiated with $2 \mathrm{kGy}$ (Air/2kGy) and 4) vacuum-packed and irradiated with $2 \mathrm{kGy}$ (Vacuum/2kGy). The irradiation process was performed at Centro Tecnológico do Exército by exposing the samples to a ${ }^{137} \mathrm{Cs}$ gamma source to a $2 \mathrm{kGy}$ dose.

In the second phase of experiments, fillet samples were obtained in the same conditions as in phase 1 out of $2 \mathrm{~kg}$ of fresh poultry breast. The samples were aseptically divided in 20 pieces of $18 \mathrm{~g}$ and were individually packed in nylonpolibarrier pouches. However different packing atmosphere was tested, yielding two sets of samples: 1) modified atmosphere packed (MAP /0kGy) and 2) modified atmosphere packed and irradiated with 2 kGy (MAP /2kGy). The gas mixture used was $80 \% \mathrm{CO}_{2}$ and $20 \% \mathrm{~N}_{2}$.

\section{Bacteriological analyses}

The samples were stored at $1^{\circ} \mathrm{C} \pm 1^{\circ} \mathrm{C}$ during the experiments and bacterial tests were performed on days $1,3,5$, 7, 9, 12 and 18 of storage. The following growth media and analytical procedures were included: plate count agar (PCA; Merck) for counting of heterotrophic aerobic mesophilic bacteria (HAMB) and heterotrophic aerobic psychrotrophic bacteria (HAPB); Violet Red Bile Glucose Agar (VRBG; Himedia) for counting of enterobacteria; Man, Rogosa and Sharpe Agar (MRS; Himedia) on double layer for lactic acid bacteria (LAB); Oxford Listeria Base (Himedia) with Listeria Selective Supplement (Oxford Formulation; Oxoid) (SR0140) for counting of Listeria spp.; Mac Conkey Agar with Yersinia Selective Supplement (SR109; Oxoid) for Yersinia spp. and Starch-ampicillin Agar (SA; Himedia) enriched with 1\% ampicilin for Aeromonas spp..

In addition, Merck`s miniaturized methodology (16), as modified by Franco and Mantilla (8), was used for coliform enumeration. It consisted of employing automatic pippetors connected to sterilized pointers for preparation and inoculation of $0.1 \mathrm{~mL}(100 \mu \mathrm{L})$ from different dilutions into $1 \mathrm{~mL}(1000 \mu \mathrm{L})$ 
of Fluorocult selective broth.

Sample preparation required $162 \mathrm{~mL}$ of peptonized saline solution at $0.1 \%$ for dilution to $10^{-1}$ followed by homogenization in a stomacher. Serial dilutions to $10^{-6}$ were then performed and poured onto plates that were then incubated at $35-37^{\circ} \mathrm{C}$ for 24 to 48 hours, excepting those prepared for counting of $\mathrm{PAHB}$, that were kept in refrigerators at $4^{\circ} \mathrm{C}$ for 7 to 10 days.

A Quebec-type colony counter provided readings of counts and by inspection of morphological and tinctorial characteristics the identification of the species of bacteria were performed. Such data were then expressed as log CFU/g.

In addition, enumeration readings of coliforms were obtained by using ultraviolet light inside a dark room. The presence of thermotolerant coliforms was confirmed by adding the Kovacs reagent for the indol test. The Most Probable Number (MPN) was determined by using Mac Crady`s table and multiplying the result by 10 in order to account for the fact that inoculation was 10 times smaller than the standard. The data were then converted into log units of the Most Probable Number/g (log $\mathrm{MPN} / \mathrm{g})$.

\section{Sensory evaluation}

Acceptance tests were used in the sensory evaluations. Samples from the different treatments were randomly submitted to the appreciation of 33 untrained judges for evaluation of color and overall impression according to a ninepoint hedonic scale, 9 corresponding to "disliked extremely" and 1 "liked extremely". Scores from 1-5 were considered acceptable.

\section{Statistical analysis}

Due to the fact that the bacterial populations in the beginning of the two phases were different, normalization to the initial reading of each phase was applied to all data of the corresponding phase so that the bacterial growth during both phases could be compared and described according to the modified Gompertz`s equation (11) by using an specific computer program, DMFIT, based on predictive microbiology (4). The shelf life of meat was then considered equal to the time needed for the counting of heterotrophic aerobic mesophilic bacteria to reach $7 \log \mathrm{CFU} / \mathrm{g}$.

The significance of differences between sensory parameters was determined by using the one-way ANOVA test along with Tukey's post test using the SAS program. Differences at $\mathrm{p}<0,05$ were considered to be statistically significant.

\section{RESULTS AND DISCUSSION}

The results are summarized in Table 1, 2, and Figure 1. The initial value of HAMB (day 0) was $5.5 \log \mathrm{CFU} / \mathrm{g}$ (for samples analyzed on first phase) and $5.8 \mathrm{log} \mathrm{CFU} / \mathrm{g}$ (for samples packed in MAP). Regarding shelf life extension, the poultry fillets packed in modified atmosphere and irradiated were those that had their shelf life doubled to 10 days, followed by those that were air and vaccum packed that were also irradiated (9 days). Then came the unirradiated samples (MAP and vacuum) (7 days) and finally the unirradiated samples packed in atmospheric air, that had a shelf life of only 5 days at $1{ }^{\circ} \mathrm{C} \pm 1{ }^{\circ} \mathrm{C}$. Such results indicate that gamma irradiation potentialized the conservation effects of MAP and efficiently extended the shelf life of the product.

Patsias et al. (24) also noted that poultry fillets refrigerated at $4{ }^{\circ} \mathrm{C}$ MAP-packaged $\left(\begin{array}{llll}70 \% & \mathrm{~N}_{2}-30 \% & \mathrm{CO}_{2}\end{array}\right)$ reached such limit after 10-12 days. Similarly, Chouliara et al. (5) reported an increase in the shelf life of irradiated poultry meat packed in modified atmosphere and, as the count of total bacteria in samples packed in air reached $7 \log \mathrm{CFU} / \mathrm{g}$ on the $5^{\text {th }}$ and $6^{\text {th }}$ days of storage at $4^{\circ} \mathrm{C}$, in agreement with the findings in this work. However, the researchers also found a longer shelf life, equal to 25 days, for fillets in MAP $\left(\mathrm{CO}_{2} / 30 \% 70 \% \mathrm{~N}_{2}\right)$ irradiated with $2 \mathrm{kGy}$. A lower initial microbial load (4.3 $\log \mathrm{CFU} / \mathrm{g}$ ) could possibly explain the longer shelf life relatively to the findings in this work since it is 
achieve the same final population of bacteria is (9). In addition, concentration of $\mathrm{CO}_{2}$ required for reduction of that microbiota the greater the amount of bacteria present is, the higher the becomes (23).

Table 1. Shelf-life and bacterial growth parameters of poultry breast fillets wrapped in air, vacuum and modified atmosphere and irradiated $(2 \mathrm{kGy})$ or not irradiated $(0 \mathrm{kGy})$ and kept at $1^{\circ} \mathrm{C} \pm 1^{\circ} \mathrm{C}$ for 18 days.

\begin{tabular}{|c|c|c|c|c|c|c|c|c|c|c|}
\hline \multirow{2}{*}{$\begin{array}{c}\text { Treatment } \\
\text { (Packing/(Dose) }\end{array}$} & \multirow{2}{*}{$\begin{array}{c}\text { Shelf Life } \\
\text { (days) } \\
\text { Based on } \\
\text { Limit: 7log CFU/g }\end{array}$} & $\begin{array}{c}\text { Bacterial Growth } \\
\text { Parameters }\end{array}$ & \multirow[t]{2}{*}{ HAMB $^{a}$} & \multirow[t]{2}{*}{ HAPB } & \multirow[t]{2}{*}{ Ent } & \multirow[t]{2}{*}{$\mathbf{C T}$} & \multirow{2}{*}{$\begin{array}{l}\text { CTer } \\
\text { ycle } \\
\end{array}$} & \multirow[t]{2}{*}{ La } & \multirow[t]{2}{*}{ Lis } & \multirow[t]{2}{*}{ Aero } \\
\hline & & Initial count normalized to 1.0 log cycle & & & & & & & & \\
\hline Air / 0 kGy & 5 & $\mathrm{~g}^{b}$ & 0,6 & 0,5 & - & 0,4 & 1,1 & 1,6 & 0,5 & - \\
\hline & & $\operatorname{Lag}^{c}$ & 1,9 & 2,2 & 1,2 & 2,4 & 8,9 & - & 1,4 & - \\
\hline & & $\mathrm{CF}^{\mathrm{d}}$ & 4 & 3,9 & 3 & 1,1 & 1,7 & 2,1 & 2,4 & nd \\
\hline \multirow[t]{4}{*}{ Vacuum / 0 kGy } & 7 & & & & & & & & & \\
\hline & & $\mathrm{g}$ & 0,7 & 1,2 & 0,4 & 0,7 & - & 5,3 & 0,2 & - \\
\hline & & Lag & 3,8 & - & 5,1 & 2,8 & - & 8,7 & 4,2 & - \\
\hline & & $\mathrm{CF}$ & 3,8 & 3,7 & 2 & 1,0 & $\mathrm{nd}^{e}$ & 1,6 & 1,7 & nd \\
\hline MAP/ & 7 & & & & & & & & & \\
\hline \multirow[t]{3}{*}{$0 \mathrm{kGy}$} & & $\mathrm{g}$ & 0,5 & 1,5 & 1,4 & 0,4 & - & 0,5 & - & - \\
\hline & & Lag & 4,8 & 4,2 & 4,7 & 5,3 & - & 6,3 & - & - \\
\hline & & $\mathrm{CF}$ & 2 & 2,6 & 1,2 & 0,9 & nd & 1,4 & nd & nd \\
\hline \multirow[t]{4}{*}{ Air / 2 kGy } & 9 & & & & & & & & & \\
\hline & & $\mathrm{g}$ & 0,7 & 6,5 & 2,3 & 1,7 & - & 0,6 & - & - \\
\hline & & Lag & 5 & - & 7,8 & - & - & 12,4 & - & 7,7 \\
\hline & & $\mathrm{CF}$ & 3,3 & 1,6 & 0,7 & 1,1 & nd & 1,8 & nd & 0,8 \\
\hline \multirow[t]{4}{*}{ Vacuum / 2 kGy } & 9 & & & & & & & & & \\
\hline & & g & 1 & 1,7 & 1,7 & 1,7 & - & 0,9 & - & 0,8 \\
\hline & & Lag & 4,4 & 1,8 & 3,8 & 6,9 & - & 2,3 & - & 7,7 \\
\hline & & $\mathrm{CF}$ & 2,7 & 1 & 0,5 & 0,7 & nd & 2,4 & nd & 0,7 \\
\hline MAP/ & 10 & & & & & & & & & \\
\hline \multirow[t]{3}{*}{$2 \mathrm{kGy}$} & & g & 0,6 & 0,6 & - & - & - & 0,4 & - & - \\
\hline & & Lag & 3,3 & 9,4 & - & - & - & 4,1 & - & - \\
\hline & & CF & 1,7 & 2,6 & nd & nd & nd & 2,6 & nd & nd \\
\hline
\end{tabular}

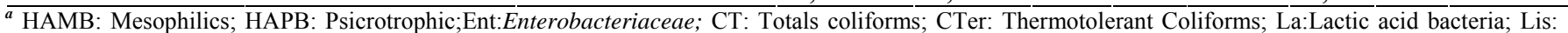
Listeria spp.; Aero: Aeromonas spp.

${ }_{b} \mathrm{~g}$ : Doubling time (days).

${ }^{\circ}$ Lag: Adaptation phase (days).

${ }^{d} \mathrm{CF}$ : Final Count (log CFU/g and $\log$ MPN/g for coliforms

${ }^{e}$ nd: Not detected count.

Table 2. Results of poultry fillets color and overall impression in the different treatments (Tukey analysis)

\begin{tabular}{llcc}
\hline \multicolumn{1}{c}{ Color } & \multicolumn{2}{c}{ Overall impression } \\
\hline Treatments & Mean* $^{*}$ & Mean* \\
MAP/0kGy & $5,24^{\mathrm{a}}$ & Treatments & $5,76^{\mathrm{a}}$ \\
Vacuum/0kGy & $5,0^{\mathrm{ab}}$ & MAP/0kGy $/ 0 \mathrm{kGy}$ & $5,24^{\mathrm{ab}}$ \\
Air/0kGy & $4,7^{\mathrm{abc}}$ & Air/0kGy & $4,81^{\mathrm{ab}}$ \\
Vacuum/2kGy & $3,67^{\mathrm{cd}}$ & Vacuum/2kGy & $4,57^{\mathrm{ab}}$ \\
MAP/2kGy & $3,45^{\mathrm{d}}$ & MAP/2kGy & $3,91^{\mathrm{b}}$ \\
Air/2kGy & $3,36^{\mathrm{d}}$ & Air/2kGy & $3,67^{\mathrm{b}}$ \\
\hline
\end{tabular}

*Means followed by same letters do not differ by Tukey test at $5 \%$ probability. 

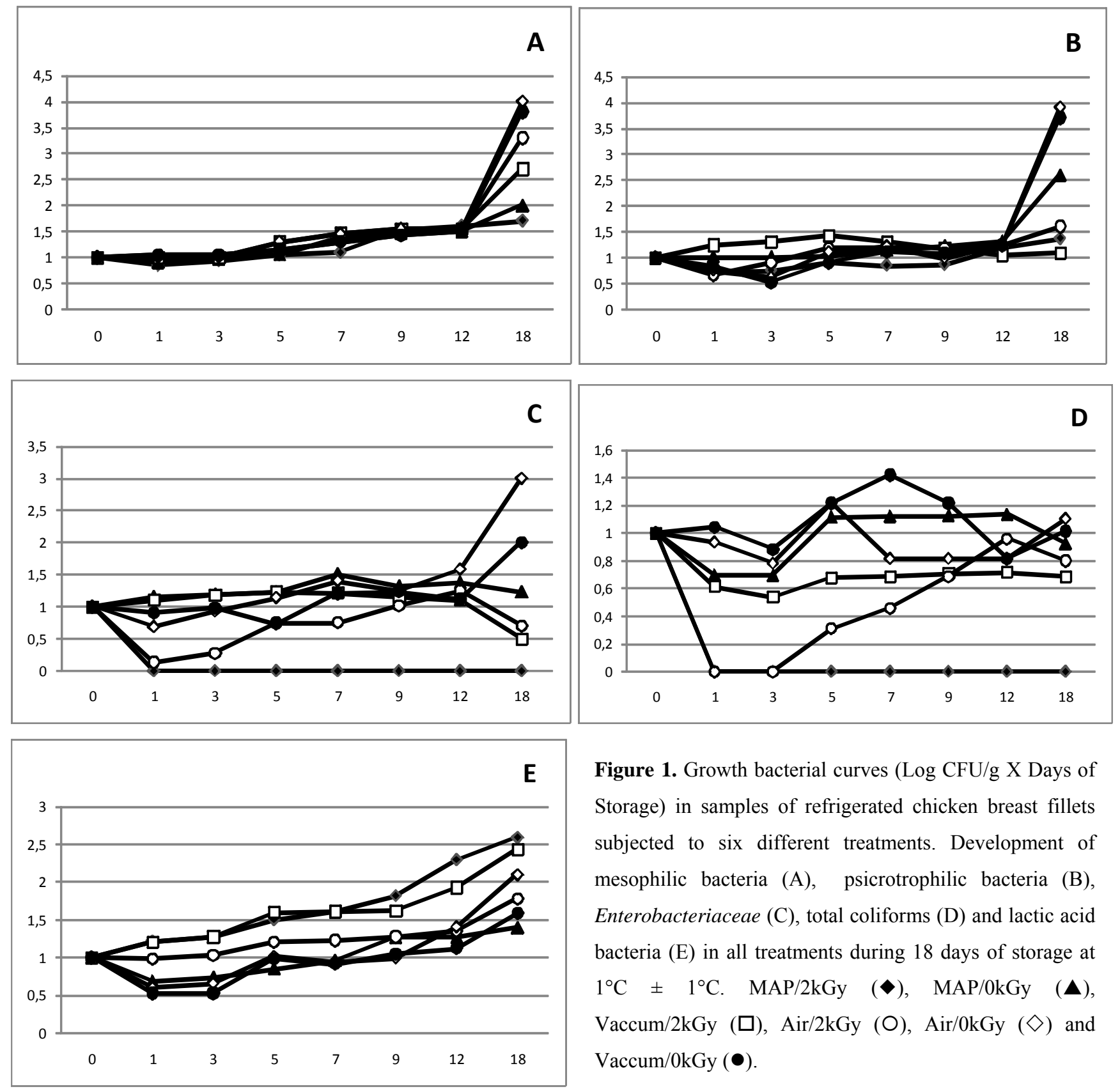

Figure 1. Growth bacterial curves (Log CFU/g X Days of Storage) in samples of refrigerated chicken breast fillets subjected to six different treatments. Development of mesophilic bacteria (A), psicrotrophilic bacteria (B), Enterobacteriaceae (C), total coliforms (D) and lactic acid bacteria $(\mathrm{E})$ in all treatments during 18 days of storage at $1^{\circ} \mathrm{C} \pm 1^{\circ} \mathrm{C} . \quad \mathrm{MAP} / 2 \mathrm{kGy}(\bullet), \quad \mathrm{MAP} / 0 \mathrm{kGy} \quad(\boldsymbol{\Delta})$, Vaccum/2kGy ( $\square)$, Air/2kGy (O), Air/0kGy $(\diamond)$ and Vaccum/0kGy (•).

According to the data from this work, the yielded the longest lag phase for mesophilic bacteria was found for air packed samples treated with $2 \mathrm{kGy}$ that had its population reduced by $2.3 \log$ cycles. That finding is in agreement with those from similar works, made by Lescano (13) and Thayer (30).

Although extending the shelf life, such treatment yielded a high population of mesophilic bacteria at the end of the experiment, possibly due to the growth of more radioresistant species, such as the lactic acid bacteria that are also more resistant to $\mathrm{CO}_{2}$ when compared with other bacterial groups.

The two methods used together have considerably 
affected the lag phase of psychrotrophic bacteria, whereas the Mantilla, S.P.S. et al.

followed by MAP unirradiated samples. The final count was higher in the control samples followed by the vacuum-packed ones. The bacterial counts of irradiated samples remained low throughout the storage period when compared with the ones subjected to MAP. Similarly, Miyagusku (17) found that samples of poultry meat packed in vacuum or modified atmosphere $\left(30 \% \mathrm{~N}_{2} / 70 \% \mathrm{CO}_{2}\right)$, irradiated with $3.0,5.0$ and $7.0 \mathrm{kGy}$ had a longer lag phase and lower counts for psychrotrophic bacteria throughout the storage period when compared with air-packed unirradiated samples.

There was no detectable growth of enterobacteria in irradiated samples treated with MAP. In addition, their longest lag phase was found for irradiated air-packaged fillets. Such result was expected because enterobacteria are very sensitive to irradiation according to several authors $(2,17,5)$. In addition, the present results are also in agreement with those reportef by Chouliara et al. (5) that enterobacteria grew more slowly under conditions of MAP $\left(30 \% \mathrm{CO}_{2} / 70 \% \mathrm{~N}_{2}\right.$ and $\left.70 \% \mathrm{CO}_{2} / 30 \% \mathrm{~N}_{2}\right)$ than in aerobiosis.

As no growth of total coliform bacteria was observed in samples packed in modified atmosphere and irradiated, it can be concluded that the combination of both processes did not allow any growth of that bacterial group. Abu-Tarboush et al. (1) also found that poultry meat irradiated with $0.5 \mathrm{kGy}$ and stored at $4^{\circ} \mathrm{C}$ had no coliforms. Irradiated samples packed in air and vaccum were found to display the longest adaptation phase, leading to very low populations at the end of the experiment.

Growth of thermotolerant coliforms was only observed in unirradiated samples packed in air, their countings remaining very low when compared with those for the other bacteria studied. Miyagusku (17) also informed the elimination of $E$. coli in irradiated samples of thigh and breast poultry meat packed in vacuum and modified atmosphere.

LAB prevailed in irradiated samples, while heterotrophic aerobic mesophilic bacteria prevailed in unirradiated samples. However, Ntzimani et al. (21) showed that lactic acid bacteria treatment MAP/2 kGy yielded the highest lag phase (9.4 days) Poultry breast fillets: bacteriological evaluation

were dominant throughout the storage period, regardless of the packaging of smoked turkey breast stored in air, vacuum and modified atmospheres $\left(\begin{array}{llll}30 \% & \mathrm{CO}_{2} / 70 \% & \left.\mathrm{~N}_{2}\right) & \text { and }(50 \%\end{array}\right.$ $\mathrm{CO}_{2} / 50 \% \mathrm{~N}_{2}$ ) kept at $4 \pm 0,5^{\circ} \mathrm{C}$ for up to 30 days. In this work, a long lag phase was observed for samples packaged in air and irradiated (12.4 days). In contrast, a short lag phase (4.1 days) was found for the irradiated MAP samples, leading to final count of lactic acid bacteria relatively higher. Such results suggest that the combined treatment did not interfere with bacterial adaptation and was not able to eliminate lactic acid bacteria as effectively as for the other bacteria studied. A possible explanation for that is that Gram positive bacteria are generally much more resistant to inhibition by $\mathrm{CO}_{2}$ and to irradiation than Gram-negative ones (9). Other authors also reported that MAP had a small effect on the population of lactic acid bacteria due to the ability of these facultative anaerobic bacteria to grow under high concentration of $\mathrm{CO}_{2}$ $(24,3,5)$.

A similar result was informed by Miyagusku (17), who found that microaerophilic conditions led to a fast adaptation of lactic acid bacteria due to the vacuum and modified atmosphere packaging that fostered their development. However, Patterson (25) found that the sensitivity of Lactobacillus sp. to irradiation was significantly higher when poultry samples were irradiated in $\mathrm{CO}_{2}$.

Listeria spp. was only detected in unirradiated air- and vacuum-packaged samples. Likewise, Zhu et al. (32) showed that irradiation (1.0 to $2.5 \mathrm{kGy}$ ) effectively reduced the number of L. monocytogenes in vacuum-packaged turkey hams and breast rolls. Samelis et al. (26) found that the dose of $4 \mathrm{kGy}$ sufficed to completely eliminate them in frozen beef.

The combination of irradiation and modified atmosphere packaging was effective in the reduction of the population of Listeria spp. in refrigerated poultry fillets. The longer adaptation phase in samples packed in vacuum led to a higher number of counts at the end of the experiments, as compared with those packed in air. 
Aeromonas spp. were not detected in the samples packed in air, vacuum and modified atmosphere. Likewise, Mano et al. Mantilla, S.P.S. et al.

inhibitory effect of $\mathrm{CO}_{2}$ on $A$. hydrophila growth in turkey meat. However, in the present study, A. hydrophila were detected in irradiated samples, suggesting a higher resistance to the process of gamma irradiation. Nevertheless, Ozba et al. (22) reported that a dose of $0.75 \mathrm{kGy}$ was sufficient to destroy approximately $10^{4} \mathrm{cfu} / \mathrm{g}$ of $A$. hydrophila in meatball.

No detection of Yersinia spp. occurred in the experiments performed in this work. According to Jay (5), pork is the most common source of those pathogens.

Sensory properties (color and overall impression) of raw poultry breast meat are given in Table 2 . In relation to the color attribute, it was observed that the treatment Air/2kGy was the one preferred by the judges, but differences were not significant at the $5 \%$ level relatively to the $\mathrm{MAP} / 2 \mathrm{kGy}$ and Vacuum/2kGy treatments. Thus, it can be concluded that packaging in modified atmosphere, used in combination with irradiation, did not significantly affect the acceptance of color. In contrast, the color of the MAP/0kGy samples was rejected, possibly due to the fact that high concentrations of $\mathrm{CO}_{2}$ can cause poultry meat to become paler, as quoted by Parry (23).

Irradiation of samples packaged in modified atmosphere or in air can cause the color of fillets to become more attractive, probably due to the intensification of a reddish coloration, as cited also by Nanke et al. (20), Lewis et al. (14), Nam and Ahn (19) and Kim et al. (12).

Regarding the scores for the overall impression (Table 2), it was found that the Vacuum/0kGy and MAP/0kGy samples were rejected. The use of $\mathrm{CO}_{2}$ in high concentrations can cause an increase in the drip of fresh meat according to Church (7), which may have contributed to the rejection by the judges. All the other treatments were accepted, with the highest scores being assigned to the Air/2kGy and MAP/2kGy samples which had similar results.
(15) failed to detect Aeromonas spp, also reporting an Poultry breast fillets: bacteriological evaluation

This study shows that the process of irradiation can turn the coloration of the poultry fillets more attractive. Also, a higher radioresistance was observed for the lactic acid bacteria when compared to the other bacterial groups analyzed. In addition, enterobacteria and coliforms were efficiently eliminated by using a combination of packaging in high concentrations of $\mathrm{CO}_{2}(80 \%)$ and irradiation. Thus it can be concluded that the combined use of modified atmosphere packaging $\left(80 \% \mathrm{CO}_{2}\right.$ and $\left.20 \% \mathrm{~N}_{2}\right)$ and gamma irradiation at a dose of $2 \mathrm{kGy}$ can significantly improve the microbiological safety of refrigerated poultry fillet, doubling its shelf life, without changing its sensory properties. Further studies should be conducted in order to determine the optimum dose and the ideal mixture of gases that would render the poultry fillets the most attractive quality and safety characteristics possible, as well as the longest shelf life achievable.

\section{ACKNOWLEDGEMENTS}

The authors gratefully acknowledge CAPES for the financial aid for the development of this research and the Nuclear Defense Section of CTEx for the irradiation of the samples.

\section{REFERENCES}

1. Abu-Tarboush, H.M; Al-Kahtani, H.A.; Atia, M.; Abou-Arab, A.A.; Bajaber, A.S.; El-Mojaddidi, M.A. (1997). Sensory and microbial quality of chicken as affected by irradiation and postirradiation storage at $4{ }^{\circ} \mathrm{C}$. J. Food Prot. 60, 761-770.

2. Balamatsia, C.C.; Rogga, K.; Badeka, A.; Kontominas, M.G.; Savvaidis, I.N. (2006). Effect of Low-Dose Radiation on Microbiological, Chemical, and Sensory Characteristics of Chicken Meat Stored Aerobically at $4^{\circ}$ C. J. Food Prot. 69 (5), 1126-1133.

3. Balamatsia, C.C.; Patsias, A.; Kontominas, M.G.; Savvaidis, I.N. (2007). Possible role of volatile amines as quality-indicating metabolites in modified atmosphere-packaged chicken fillets: Correlation with microbiological and sensory attributes. Food Chem. 104: 1622-1628.

4. Baranyi, J.; Roberts, T.A. (1994). A dynamic to predicting bacterial 
growth in food. Int. J. Food Microbiol. 23, 277-294

5. Chouliara, E.; Badeka, A.; Savvaidis, L.; Kontominas, M.G. (2008). Combined effect of irradiation and modified atmosphere packaging on Mantilla, S.P.S. et al.

6. Church, N. (1994). Developments in modified-atmosphere packaging and related technologies. Trends Food Sci. Technol. 5, 345-352.

7. Church, I.J.; Parsons, A.L. (1995). Modified Atmosphere Packaging Tecnology: A Review. J. Sci. Food. Agric., 67, 143-152.

8. Franco, R.M.; Mantilla, S.P.M. (2004). Escherichia coli em corte de carne bovina: avaliação da metodologia aplicada e sensibilidade antimicrobiana dos sorovares predominantes. In: $14^{\circ}$ Seminário de Iniciação Científica e Prêmio UFF Vasconcellos Torres de Ciência e Tecnologia, Niterói, RJ.

9. Jay, J.M. (2005). Microbiologia de alimentos. 6 ed. Artmed, Porto Alegre, $711 \mathrm{p}$.

10. Landgraf, M. (2008). Controle do Desenvolvimento Microbiano nos Alimentos. Microrganismos Patogênicos de Importância em Alimentos. In: Franco, B. D. G. M. \& Landgraf, M. Microbiologia dos Alimentos. São Paulo: Atheneu. 182 p., cap. 7, p. 109-148.

11. Gibson, A.M.; Bratchell, N.; Roberts, T.A. (1987). The effect of sodium chloride and temperature on the rate and extent of growth of Clostridium botulinum type A in pasteurized pork slurry. J Appl. Bacteriol. 62, 479490.

12. Kim, Y.H.; Nam, K.C.; Ahn, D.U. (2002). Color, Oxidation-Reduction Potential, and Gas Production of Irradiated Meats from Different Animal Species. J. Food Sci. 67 (5), 257-265.

13. Lescano, G.; Narvaiz, P.; Kairiyama, E.; Kaupert, N. (1991). Effect of chicken breast irradiation on microbiological, chemical and organoleptic quality. Lebensm-Wiss Technol. 24 (2),130-134.

14. Lewis, S.J.; Vela'Squez, A.; Cuppett, S.L.; Mckee, S.R. (2002). Effect of Electron Beam Irradiation on Poultry Meat Safety and Quality. Poultry Sci. 81, 896-903.

15. Mano, S.B.; Ordoñez, J.A.; Garcia de Fernando, G.D. (2000). Growth/survival of natural flora and Aeromonas hydrophila on refrigerated uncooked pork and turkey packaged in modified atmospheres. Food Microbiol. 17 (6), 657-669.

16. Merck. (2000). Microbiology Manual. Berlin, Germany, 407p.

17. Miyagusku, L. (2008). Influencia da radiação ionizante (60Co) na manutenção da qualidade físico-química, microbiológica e sensorial de cortes de coxa e file de peito de frango acondicionado em deferentes sistemas de embalagens. Campinas, Brasil, p. (PhD Thesis. Faculdade de Engenharia de Alimentos Universidade Estadual de Campinas).

18. Molins, R.A. (2001). Food irradiation: principles and applications. 1 ed. Wiley-Interscience, New York, 488 p. shelf-life extension of chicken breast meat: microbiological, chemical and sensory changes. Eur. Food Res. Technol. 226 (4), 877-888.

Poultry breast fillets: bacteriological evaluation

19. Nam, K.C.; Ahn, D.U. (2002). Carbon monoxide-heme pigment complexes are responsible for the pink color in irradiated raw Turkey breast meat. Meat Sci. 61, 25-33.

20. Nanke, K.E.; Sebranek, J.G.; Olson; D.G. (1998). Color Characteristics of Irradiated Vacuum-Packaged Pork, Beef, and Turkey. J Food Sci. 63 (6), 1001-1006.

21. Ntzimani, A.G.; Paleologos, E.K.; Savvaidis, J.N.; Kontominas, M.G. (2008). Formation of biogenic amines and relation to microbial flora and sensory changes in smoked turkey breast fillets stored under various packaging conditions at $4^{\circ} \mathrm{C}$. Food Microbiol,. 25, 509-517.

22. Ozbaş, Z.Y.; Vural, H.; Aytaç, S.A. (1996) Combined effect of gammairradiation and conventional cooking on Aeromonas hydrophila in meatball. Z Lebensm Unters Forsch. 202, 1, 60-2.

23. Parry, R.T. (1993). Envasado de los alimentos em atmosfera modificada. Madrid: A. Madrid Vicente, 331p.

24. Patsias, A.; Badeka, A.V.; Savvaidis, I.N.; Kontominas, M.G. (2008). Combined effect of freeze chilling and MAP on quality parameters of raw chicken fillets. Food Microbiol,. 25, 575- 581.

25. Patterson, M. (1988). Sensitivity of bacteria to irradiation on poultry meat under various atmospheres. Lett Appl Microbiol. 7, 55-58.

26. Samelis, J.; Kakouri, A.; Savvaidis, I.N.; Riganakos, K.; Kontominas, M.G. (2005). Use of ionizing radiation doses of 2 and $4 \mathrm{kGy}$ to control Listeria spp. and Escherichia coli O157:H7 on frozen meat trimmings used for dry fermented sausage production. Meat Sci. 70, 189-195.

27. Sant'Ana, A.S.; Araújo, I.O. (2007). Irradiação e a segurança e qualidade microbiológica dos alimentos. Hig. Alimentar, 21 (151), 37-51.

28. Savadogo, A.; Ouattara, C.A.T.; Bassole, I.H.N; Traore, S.A. (2006). Bacteriocins and lactic acid bacteria - a minireview. African Journal of Biotechnology 5 (9), 678-683.

29. Stone, H.; Sidel, J.L.(1998). Quantitative descriptive analysis: developments, applications, and the future. Food Techno. 5 (8), 48-52.

30. Thayer, D.W. (1995). Use of irradiation to kill enteric pathogens on meat and poultry. J Food Safety, 15, 181-192.

31. Vital, H.C.; Freire Junior, M. (2008). A irradiação de Alimentos. In: Rosenthal, A. Tecnologia de Alimentos e Inovação:Tendências e Perspectivas. Embrapa Informação Tecnológica, Brasília, DF, 193 p.

32. Zhu, M. J.; Mendonca, A.; Ismail, H. A. and Ahn, D. U. (2008). Effects of Irradiation on Survival and Growth of Listeria monocytogenes and Natural Microflora in Vacuum-Packaged Turkey Hams and Breast Rolls. Poultry Sci. 87, 2140-2145. 
